Michael Zimmer:

\title{
Innovations and Challenges in Teaching Information Ethics Across Educa- tional Contexts
}

\begin{abstract}
:
Renewed attention to integrating information ethics within graduate library and information science (LIS) programs has forced LIS educators to ensure that future information professionals - and the users they interact with - participate appropriately and ethically in our contemporary information society. Along with focusing on graduate LIS curricula, information ethics must become infused in multiple and varied educational contexts, ranging from elementary and secondary education, technical degrees and undergraduate programs, public libraries, through popular media, and within the home.

Teaching information ethics in these diverse settings and contexts brings numerous challenges and requires new understandings and innovative approaches. In keeping with the 2011 Association for Library and Information Science Education (ALISE) conference theme of "Competitiveness and Innovation," a diverse panel of educators and researchers were convened to foster a discussion in how to best incorporate information ethics education across diverse contexts, and how to develop innovative educational methods to overcome the challenges these contexts inevitably present. This article reports on that panel discussion and offers recommendations towards achieving success in information ethics education.
\end{abstract}

\section{Agenda:}

Introduction 18

Carbo: Lessons Learned 19

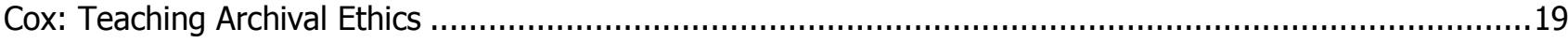

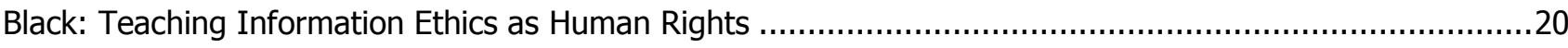

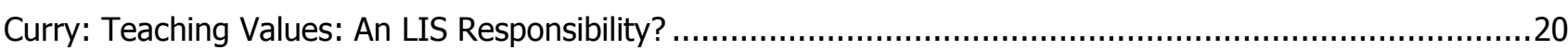

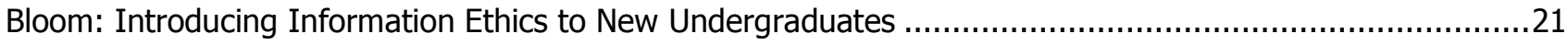

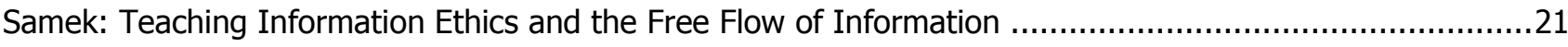

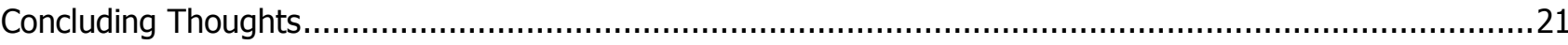

\section{Author:}

Dr. Michael Zimmer:

- School of Information Studies, University of Wisconsin-Milwaukee, 3210 N. Maryland Ave, Bolton Hall, $5^{\text {th }}$ Floor, Milwaukee, WI 53211 USA

- $\quad$ 푱 414-229-3627, $\square$ zimmerm@uwm.edu $\square$ www.MichaelZimmer.org 


\section{Introduction}

The field of information ethics is dedicated to the critical reflection on the ethical values and practices related to the production, storage, and distribution of information, as well as the ethical implications of the information systems, infrastructures, and policies increasingly embedded in modern culture and society. ${ }^{7}$ The scope of information ethics encompasses the broad relationship between information and human rights and responsibility, including ethical issues related to information production, information collection and classification, information storage, access and dissemination, and information law and policy. Thus, information ethics has become a central concern among information professionals, and features prominently both in the American Library Association's statement of Core Competencies of Librarianship (American Library Association, 2009), as well as its standards used to accredit graduate programs in library and information studies (American Library Association, 2008).

Despite the recognition of information ethics by professional organizations and accrediting authorities, coupled with calls for the integration of information ethics courses in library science programs (Carbo \& Almagno, 2001), recent studies have shown that less than half of the American Library Association's accredited programs offered such courses, and only a few of these program required students to take a course on information ethics (Buchanan, 2004).

To help refocus the need for information ethics within library and information studies curricula, the Association for Library and Information Science Education (ALISE) ratified a position statement on Information Ethics in LIS Education, which called for inclusion of information ethics within foundational courses, the creation of courses devoted specifically to information ethics, and an ongoing engagement with information ethics across the curriculum (ALISE Information Ethics Special Interest Group, 2007).

Since the statement's drafting in 2007, much substantive work has focused on ensuring infor-

\footnotetext{
${ }^{7}$ For a brief history and introduction to information ethics, see
} (Froehlich, 2005) and (Floridi, 2006). mation ethics is properly integrated in LIS graduate curricula (see, for example, Fallis, 2007; Fleischmann, Robbins, \& Wallace, 2009; Smith, 2010), culminating in a special session at the 2010 ALISE conference on "Integrating Ethics across the Curriculum in Library and Information Science". ${ }^{8}$

While this renewed attention on integrating information ethics within graduate LIS programs is both welcome and necessary, it is only a partial solution to ensuring that future information professionals -- and the users they interact with -participate appropriately and ethically in our contemporary information society. Along with focusing on graduate LIS curricula, information ethics must become infused in multiple and varied educational contexts, ranging from elementary and secondary education, technical degrees and undergraduate programs, public libraries, through popular media, and within the home.

Teaching information ethics in these diverse settings and contexts brings numerous challenges and requires new understandings and innovative approaches. In keeping with the 2011 ALISE conference theme of "Competitiveness and Innovation," a diverse panel of educators and researchers were convened to foster a discussion in how to best incorporate information ethics education across diverse contexts, and how to develop innovative educational methods to overcome the challenges these contexts inevitably present.

The panellists were:

- Toni Carbo, Drexel University Center for Graduate Studies

- Richard Cox, School of Information Sciences, University of Pittsburgh

- Kimberly Black, School of Information Science, University of Tennessee, Knoxville

- Ann Curry, Faculty of Education, University of Alberta

- Raina Bloom, School of Information Studies, University of Wisconsin - Milwaukee

\footnotetext{
${ }^{8}$ Details at http://www.alise.org/mc/page.do?sitePageId=101955\#6
} 
- Toni Samek, School of Library \& Information Studies, University of Alberta

The particular experiences and insights shared by each panelist are summarized below. Taken together, these diverse - yet intertwined - set of reflections can help guide our efforts for incorporating information ethics education in a range of educational contexts and domains of everyday life.

\section{Carbo: Lessons Learned}

Dr. Toni Carbo, while at the University of Pittsburgh, developed and co-taught one of the first courses on Information Ethics in an LIS graduate program, and remains one of the field's leading educators.

Carbo shared her experiences and lessons learned from her involvement in the teaching, research and development of codes of ethics for organizations like ALISE and the Special Library Association (SLA), and how those experiences can be incorporated into teaching information ethics across contexts.

A key factor in Carbo's experiences was to ensure a diversity of specializations, levels of expertise, and cultural backgrounds among participants. As an educator, we must incorporate different cultural views and global perspectives. While it takes considerable effort to foster the right dialogue among a diverse set of students, the payoff comes in rich conversations, balanced deliberations, and collaborative analyses of ethical problems.

To achieve success in information ethics education, Carbo urged a continued emphasis on the careful use of language, as well as the focus on imparting critical thinking skills. As educators, she warned, we must avoid "simplistic dichotomies" when discussing complex ethical issues and consider all possible perspectives. Further, we must convey attitudes of openness and understanding of diverse perspectives, but at the same time question assumptions and critically interrogate longstanding attitudes and positions. Through these strategies, we can help our students to think critically, and not just react with expected responses, leading to students better armed to address complex ethical dilemmas when they leave our classrooms.

\section{Cox: Teaching Archival Ethics}

Dr. Richard Cox is a leading researcher and teacher in the area of archives and records management, focusing largely on the ethical dimensions of archival work. During the panel discussion he shared the evolution of his experiences "teaching archival ethics" which, he stressed, must take place both in the classroom and through research and publications.

Cox discussed the widening role that archival records play in society. As opposed to most writings in the discipline of archives and records management which view records from cultural, historical, and economical efficiency dimensions, his scholarship highlights that one of the most salient features of records is the role they play as sources of accountability -- a component that often brings them into daily headlines and into courtrooms. Struggles over control, access, preservation, destruction, authenticity, accuracy, and other issues demonstrate time and again that records are not mute observers and recordings of activity. Rather, they are frequently struggled over as objects of memory formation and erasure.

Thus, an increasing number of ethical issues confront today's archivists, which Cox suggests leads to a kind of "archival anxiety:"

A substantial portion of the archival profession is anxious about a variety of issues. The challenges archivists face are the result of a growing recognition of the importance of records in our society and its organizations, although these challenges are pushing archivists to think well beyond the cultural mission so many archivists have chosen to emphasize. The days of archivists sitting quietly in their stacks and waiting for the occasional researcher to appear are long gone (if they ever really existed). Archival anxiety may be the result of this community being shaken out of its complacen$c y$.

To help address this new anxiety within the archival profession, Cox has developed a robust course on Archival Access, Advocacy, and Ethics, which introduces the contentious and controversial issues confronting archivists to students who are just discovering the archival field and who are often more concerned with practical skills than philosophical and political quagmires, or who bring false and uninformed notions of the archival mission and work with no room (at least initially) 
for ethical concerns. To ensure critical engagement with emerging ethical issues, Cox designed the course to produce articles co-authored with students that have appeared in First Monday and special issues of Library and Archival Security (Spring 2009) and the Journal of Information Ethics (Spring 2010).

Through these modes of teaching with archival students, Cox hopes to move the discussion and deliberation on archival ethics into the public sphere, shifting the focus away from the inner workings of the professional community, towards an intellectual engagement with the general public to gain a fuller understanding of the relevant ethical problems and possible solutions.

\section{Black: Teaching Information Ethics as Human Rights}

Dr. Kimberly Black argued that information ethics should be considered a dimension of human rights, and revealed how the Universal Declaration of Human Rights, and its related Covenants, provides educators - as well as advocates - a helpful framework to approach information ethics within the broader human rights discourse.

According to Black, Article 15 of the International Covenant on Economic, Social and Cultural Rights (ICESCR $)^{9}$ is particularly important for proponents of information ethics. This section requires signing governments to recognize the right of everyone to "enjoy the benefits of scientific progress and its applications" and to take the necessary steps to help people realize this right, including "those necessary for the conservation, the development and the diffusion of science and culture." In the language of information ethics, these requirements correspond with concerns over information access, intellectual property, intellectual freedom, and the ethical development of information technologies as well as ethical information practices.

Black urged LIS educators to join with other academic organizations - such as the American Association for the Advancement of Science - in the pursuit of clarifying and applying the language of Article 15 to ensure these information-based rights are fully enjoyed by all. Specifically, the LIS community should work to help infuse "rights talk" within information ethics courses and discussions, and build new conceptual frameworks that include rights and ethics that cut across areas of practice.

\section{Curry: Teaching Values: An LIS Responsibility?}

Dr. Ann Curry, whose research focuses on the role of intellectual freedom in maintaining human rights and democracy, spoke on the responsibility librarians have to promote intellectual freedom and equity of access to information across educational levels and contexts.

While the latest research studies reveal how personal values develop in children as they mature and early exposure to ethical discussions benefit that development, Curry warned of a growing trend away from engaging in discussions of values and ethics in the classroom, due to fears of being controversial, causing conflicts with parents or administrators, and general discomfort with the need to confront complicated moral and ethical debates. Her informal review of primary and secondary school curricula across Canada revealed no specific mention of intellectual freedom or the right of individuals to read what they choose, no mention of connection between and "informed electorate" and democracy, and no mention of the role of libraries in supporting these values.

Curry argued that if we really believe that intellectual freedom is important and crucial to democratic societies, and if we believe that intellectual is an important LIS value, we must lobby for more presence of information ethics and its related values in primary and secondary school curricula. Specifically, she called for:

We, LIS instructors and professionals, must be more "upfront" about intellectual freedom as a library value

- We must promote intellectual freedom more vigorously in the public sphere

- We must lobby for a greater presence of intellectual freedom related democratic values in the $\mathrm{K}-12$ school curriculum

- We must promote more vigorously in schools and in libraries the importance of informed, respectful discussion of our differences of opinion

\footnotetext{
${ }^{9}$ http://www2.ohchr.org/english/law/cescr.htm
} 
- We must promote to government and to the general public the role of libraries in providing both the forums and the background materials for such discussions

In short, if we hold intellectual freedom as one of our core LIS values, and if we believe that intellectual freedom is the foundation of democracy, we have a responsibility to promote the teaching of intellectual freedom values, not only in LIS graduate programs, but also in the $\mathrm{K}-12$ curriculum.

\section{Bloom: Introducing Information Ethics to New Undergraduates}

Raina Bloom, who coordinates undergraduate information literacy courses at the University of Wisconsin-Milwaukee, argued that information ethics is a necessary part of undergraduate information literacy education, particularly at the introductory level. Many research practices taught at this level are, at their base, ethical considerations - proper citation, for example - and the ethical dimensions of these skills should be made explicit. Even the simplest bibliographic research, Bloom has found, is deeply entangled in the increasingly complex realities of the information society.

Bloom relayed a story of a student from her information literacy course who, when told that a Wikipedia article was not a suitable source for research, appealed with the remark "What if it's a really good Wikipedia entry?". Suddenly, issues of information ethics moved to the forefront of this particular lesson in information literacy: what makes Wikipedia "good" or "bad"? According to whom? And why? Students are familiar with popular information objects like Wikipedia, and we must make use of such moments, Bloom argued, to ask important ethical questions about that information source's relative reliability, authenticity, neutrality, and so on. Through such ethical interrogation, we can lead students towards a more critical engagement with their informational surroundings.

Similarly, Bloom drew from critical literacy theorists, such as Paulo Freire, Henry Giroux, and Maxine Green, to compel us to follow Carbo's advice (above) and build from our students' diverse backgrounds and experiences to help them gain better insights into the problematics of information ethics and information literacy. As educa- tors, we should use our students' lived experiences - as well as our own - to better relate the nuances of novel ethical dilemmas and what it means to be truly information literate.

\section{Samek: Teaching Information Ethics and the Free Flow of Information}

Toni Samek writes and teaches on topics in critical librarianship, intellectual freedom, and routinely urges librarians to take social action in order to advance human rights. Samek spoke of her graduate course titled Intellectual Freedom and Social Responsibility in Librarianship, which engages students in a range of ethical issues, such as intellectual freedom, free flow of information, the public good, and democratic frameworks, as well as counter pressures, such as capitalist efficiency.

Samek noted that to properly engage with information ethics instruction from a critical stance, you must extend your framework into emergent information ethics terrains such as knowledge economy, indigenous knowledge, cybernetic pluralism, and global tightening of information and border controls. In her experience, she would find herself immersed in rhetoric and reality contestations over internationalization of higher education, the contingent worker model, the meaning of global citizenship education and research, and academic freedom in the 21st century.

The necessity of critically reflecting on how we teach information ethics was made clear to Samek when a student who lives part-time in another country, where the free flow of information is not tolerated, asked: "is the online class website secure?" The answer was "no", which prompted Samek to recognize the need for broader contemplation and conversation about the relationships between teaching information ethics, the importance of a free flow of information in the global academic enterprise, and aggressive marketization and internationalization of higher education.

For a more detailed discussion of these concerns, see Samek's contribution in this issue.

\section{Concluding Thoughts}

As we consider the vital importance of teaching information ethics within our LIS graduate pro- 
grams, this panel discussion sparked various challenges - and opportunities - to integrate information ethics across diverse educational contexts, to frame information ethics within multiple discourses, and to critically reflect on the ethical implications of our pedagogical methods and environments themselves.

To answer these calls to action, the LIS community of educators and professionals will need to explore new ways to encourage and capitalize on a diversity of perspectives within the information ethics classroom; we will need to provoke critical thinking and push students into new intellectual terrain; and we will also need to critically interrogate our own language and positioning when we teach information ethics.

\section{References}

ALISE Information Ethics Special Interest Group. (2007). Position Statement on Information Ethics in LIS Education. Retrieved January 14, 2011, from http://www.alise.org/mc/page.do?sitePageld= 58273.

American Library Association. (2008). Standards for Accreditation of Master's Programs in Library and Information Studies. Retrieved January 14, 2011, from http://www.ala.org/ala/educationcareers/educ ation/accreditedprograms/standards/standards _2008.pdf.

American Library Association. (2009). ALA's Core Competences of Librarianship. Retrieved January 14, 2011, from http://www.ala.org/ala/educationcareers/care ers/corecomp/corecompetences/finalcorecomp stat09.pdf.

Smith, B. T. (2010). Ethics instruction in library and information science : the role of "ethics across the curriculum". Unpublished Dissertation, University of Rochester.

Buchanan, E. (2004). Ethics in library and information science: What are we teaching? Journal of Information Ethics, 13(1), 51-60.

Carbo, T., \& Almagno, S. (2001). Information ethics: the duty, privilege and challenge of educating information professionals. Library Trends, 49(3), 510-518.

Fallis, D. (2007). Information ethics for twentyfirst century library professionals. Library Hi Tech, 25(1), 23-36.
Floridi, L. (2006). Information ethics, its nature and scope. Computers \& Society, 36(3), 2136.

Froehlich, T. (2005). A Brief History of Information Ethics. Computer Society of India, 28(12), 1113.

Fleischmann, K., Robbins, R., \& Wallace, W. (2009). Designing Educational Cases for Intercultural Information Ethics: The Importance of Diversity, Perspectives, Values, and Pluralism. Journal of Education for Library and Information Science, 50(1), 4-14. 